\title{
The Development of Indicators for Transformational Leadership of Undergraduate Students at Thailand National Sports University
}

\author{
Thitipong Sukdee ,* $^{*}$ \\ ${ }^{1}$ Faculty of Education, Thailand National Sports University, Chon Buri 10110, Thailand \\ *Correspondence: Thailand National Sports University, 111 Sukhumvit, Nongmaidaeng, Meung, Chon Buri 20000, \\ Thailand. Tel: 66-89-855-4100. E-mail: peter_book_ja@hotmail.com
}

Received: October 18, 2020

Accepted: December 20, $2020 \quad$ Online Published: February 16, 2021

doi:10.5430/wje.v11n1p94

URL: https://doi.org/10.5430/wje.v11n1p94

\begin{abstract}
This paper develops indicators for transformational leadership of undergraduate students at Thailand National Sports University. The development of these indicators was based on in-depth interviews with six informants. The research instrument was a semi-structured interview form. The data collected were inductively analyzed. The development of indicators was accomplished through the synthesis of the data and the conceptual framework for this research investigation. Evaluate indicators of Accuracy Standard Propriety Standard with of five experts was compared with the principle of 3.50, using the research instrument was an Evaluation Form and thence the verification of the quality of the congruence of the indicators. The sample population consisted of 450 undergraduate students at Thailand National Sports. The research instrument was a rating-scale questionnaire. Confirmatory factor analysis (CFA) was utilized in conjunction with reliance on the maximum likelihood estimation (MLE) technique.

Findings were as follows: 1) In regard to the development of indicators for transformational leadership of undergraduate students at Thailand National Sports University, results were as follows: The aspect of idealized influence engendered eight keywords and twenty-two subtopics. The aspect of inspiration motivation exhibited six keywords and thirteen subtopics. The aspect of intellectual motivation evinced six keywords and fourteen subtopics. The aspect of individualized consideration displayed five keywords and eleven subtopics. 2) Assessing indicators for transformational leadership of undergraduate students at Thailand National Sports University All aspects were significantly higher than the threshold 3.50 at the .05 level. 3) The development of indicators for transformational leadership of undergraduate students at Thailand National Sports University were found to have twenty-five indicators. The verification of the quality of appropriateness for the indicators for transformational leadership of undergraduate students at Thailand National Sports University showed that chi-square $(\chi 2)$ was at 552.93; (probability-value [p-value] at 0.000); degrees of freedom (df) at 271; relative $\chi 2$ at 2.04; goodness of fit index (GFI) at 0.91; adjusted goodness of fit index (AGFI) at 0.90; Normal Fit Index (NFI) at 0.99; Comparative Fit Index (CFI) at 0.99 and the root mean square error of approximation (RMSEA) at 0.04 . It is concluded that transformational leadership of undergraduate students at Thailand National Sports is consistent with empirical data.
\end{abstract}

Keywords: transformational leadership, undergraduate students, Thailand national sports university

\section{Introduction}

Thailand is currently in the middle of competitive globalization, especially in regards to economy. Furthermore, technological advancements provide instant distribution of news and information. The influx of foreign cultures into Thailand via digitalized society caused changes that inevitably require adaptation. Societies that cling to the same foundations will not develop. Changes affect values, attitudes, and life behaviors (Office of the National Economic and Social Development Board, 2017). Higher education institutions are also required to adapt to situational changes in the world's society. Modern education is essential to national development. It is a factor that drives nations toward prosperity. Using information and communication, knowledge-gathering, and applying this knowledge are key to competitive advantages. Technological advancements nowadays have led to a myriad of hardware and software. Wireless devices and satellite technology are established to the point of indispensability. Costs for telecommunication have been reduced. These result in access and exchange of information that can be done anytime and anywhere without the obstruction of borders, as was true in the past (The Commission drives the country's 
reform, 2017). In addition, mobile technology has been playing larger roles in learning. Mobile devices are now able to improve the learning process. Universities have turned to mobile technology to adapt to changes and effectively provide knowledges (Alshehri \& Cumming, 2020). The use of e-learning in learning applications has played important roles in communication and facilitation of more effective information sharing. Students connect to the internet and communicate via platforms that allow them to converse in real time (Taat \& Francis, 2020). This has greatly affected educational management. These changes also affect attitudes and responses to changes, both positively and negatively, among those involved in education. The first group affected is traditionalist. This group admires the events of the past and does not recognize the necessity for changes. They feel a sense loss, enmity, and disagreement. The second group affected is adaptors. This group also gives importance to the past and is concerned about change, but as time passes, they start to explore options. The last group affected is innovators. This groups constantly envisions the future. They explore and experiment with new things. They are actively trying to integrate tools to sustain the changes (Sangkhawan, 2015).

In order for graduates to enter the professional and labor market, they need leadership to ensure their success. Leadership is a quality sought after by all organizations, especially those in dire need of executives with leadership qualities, since they can inspire individuals in their teams to commit their energy with full potential and work determinedly in unison. This will drive the organization to grow and successfully make progress. Effective leaders are necessary to build societies (Meepadung, Noichun Yafu, 2015). Leaders possess the art of leading and motivating others. They constantly learn and excel in communication. They possess vision and intelligence. A good leader trusts his or her team. Good leaders maintain positive image and set good examples, rather than a pretentious image of an effective and moral person (Bennis, 2009). Leadership needs to be built and instilled from an early age. Leadership in students plays an important role in initiating projects, student activities, and other student operations. Student operations also require selfless leaders with plans for work. However, student leaders may still lack skills to lead their groups, which may result in unsuccessful operations and activities. Moreover, there is still little study in Thailand on transformational leaderhip in students. Most studies are conducted on organization leaders. Transformational leadership is able to make a difference and bring new ideas to leaders. In turn, leaders will gain trust, admiration, loyalty, and respect from followers. They can work with their followers, share information, foster morality and ethics, and motivate them to effectively perform their tasks (Yukl \& Gardner, 2020)

Originally named the Institute of Physical Education, Thailand National Sports University is a government university under the oversight of the Ministry of Tourism and Sports. In 2019, its mission is to produce and develop human resources to support and promote education in accordance with the government policy. It provides undergraduate courses in every region of Thailand, with a total of 17 campuses. It is tasked with the production and development of human resources in education, sports, sports science, health science, recreational activities, and other related fields. It also promotes research in the fields of physical education, sports, sports science, health, science, recreational activities, etc. It also provides services to society and supports arts and culture, as well as traditional games and sports. It has three faculties for students to enroll with their preferences, consisting of the Faculty of Education, Faculty of Sports and Health Science, and Faculty of Arts. The university emphasizes the production of personnel in sports industry, development of sports for careers and superiority. It promotes income from sports in order to create jobs, careers, and add economical value to the nation (Thailand National Sports, 2018). According to the Sixth National Sports Development Plan (2017-2021), Strategy Four on Modernizing Sports Learning in Higher Education Institutes, there should be development of knowledge in fields related to sports in the country. Also, sports education via public media should be promoted in order to attract students and increase the number of quality sports personnel (Office of the Permanent Secretary of Ministry of Tourism and Sports, Thailand, 2016). Therefore, leadership is important to social development and is a crucial mechanism for more positive changes. As a student, if one lacks supportive environment promoting leadership, one might become an adult without leadership. Thus, it is appropriate to develop leadership during one's period as a student in order to create a society with leadership (Skalicky et al., 2020). Development of leadership in students is a duty of higher education institutes. Students should drive the development of leadership among themselves. Treating one's classmates as colleagues helps organizations overcome traditional employment processes and develop their identity as a leader, preparing themselves to be a professional one (Gott, Bauer, \& Long, 2019). Creation of a transformative environment facilitates students' learning, helping them mature as adults with high level of leadership (Dempster \& Lizzio, 2007; Rosch \& Collins, 2017). This is why it is highly necessary to study leadership at an educational age, especially in university. These students are important resources to the nation and it is expected that university graduates be role models for the general public, be a visionary, possess interpersonal skills, and be able to manage affairs effectively. They should also utilize their knowledges to develop the country and create positive change in society as educated individuals. For this reason, it is 
necessary for students to possess transformational leadership. Ustun (2018) studied transformational leadership behaviors of high school students according to leisure preference and participation type. Study results showed that students who prefer physical activities in their leisure time scored significantly higher than students who preferred home-based or social activities. When we think about the positive aspects of physical activities on human behavior in the extent of leadership, this result is predictable. Moreover, Minhyun, Glenn, Lauren, \& Hosung (2017) found that transformational leadership had a positive impact on students' expectancy-value and intrinsic motivation. Additionally, based on multiple regression, intellectual stimulation was a common factor that positively affected students' expectancy-value and intrinsic motivation. The results of the study supported the importance of transformational leadership that affects middle school students' intrinsic motivation and expectancy-value in physical education. It is recommended that physical education teachers be able to understand and display appropriate leadership, in particular transformational leadership. Transformational leadership is a theory on leaders that best explains internal changes in organizations. (Beer, 2010) and Ewell (2018) stated that transformational leadership within a university's student organization promotes bond between its members and help increase member count. Moreover, transformational leaders are able to achieve the organization's goal effectively. This coincides with Crowne (2019)'s research, which found that transformational leadership is important. It promotes creativity and value. Furthermore, transformational leadership is correlated to cultural intelligence and personality.

There has been little research on student leadership in Thailand. Most previous studies were conducted on working adults. However, theories on leadership can be studied and create understanding on student leadership. There have been a number of previous studies on transformational leadership in university students. Neumeister (2017) summarized his findings in "The Model of Transformational Change for Moral Action: A Conceptual Framework to Elevate Student Conduct Practice in Higher Education" and Nurtjahjani, Noermijati, Hadiwidjojo, \& Irawanto, (2019) published "Transformational Leadership in Higher Education: (A Study in Indonesian Universities)." They explored Bass (1999)'s concept that transformational leadership consists of idealized influence, inspiration motivation, intellectual stimulation, and individualized consideration. Moreover, the transition from the Institute of Physical Education into Thailand National Sports University attracted curiosity among the researchers. This led to the question of what transformational leadership indicators in undergraduate students at Thailand National Sports University are and whether undergraduate students at Thailand National Sports University agree with said indicators. We are keen to develop indicators for transformational leadership among undergraduate students at Thailand National Sports University. The purpose of this study is to serve as a guideline in developing leadership suitable for the transition. We hope to increase the effectiveness of students' work for the benefit of further undergraduate course management.

\section{Method}

\subsection{Objectives}

1) To develop indicators for transformational leadership of undergraduate students at Thailand National Sports University.

2) To verify consistency of indicators for transitional leadership of undergraduate students at Thailand National Sports University.

\subsection{Conceptual Framework}

By studying relevant research on transformational leadership by Jovanovica \& Ciric (2016), who studied the benefits of transformational leadership in the context of education, we found that the transformational leadership style is the most suitable for guiding the students within the school conditions. This type of claim has its basis in these three points: 1) the ethical dimension of transformational leadership, that is, the moral basis; 2 ) the validity of previous researches supported by evidence; and 3) evidence of the leaders' practice in the field of education. Shabazz (2020) found that transformational leaders encourage, inspire, and motivate others. Understanding transformational leadership will allow teachers to create positive environments for their students to be successful. Fardillah, Prasetyo \& Rizca Putri (2018) found that the influence of transformational leadership style to organizational commitment through job satisfaction. Melanie \& Vilmos (2019) found that transformational leadership could offer an important approach for the future of higher education in this dynamic, global environment. Abubakar \& Ahmed (2017) found that transformational leadership style had a significant positive effect on university performance. Improved university performance can address the problem of under-performing universities. The researchers explored Bass (1999)'s concept of transitional leadership in the aspect of "Four I's". Latent variables were created as follows: 
idealized influence (II), inspiration motivation (IM), intellectual stimulation (IS), and individualized consideration (IC). as shown in the conceptual framework as shown in Figure 1

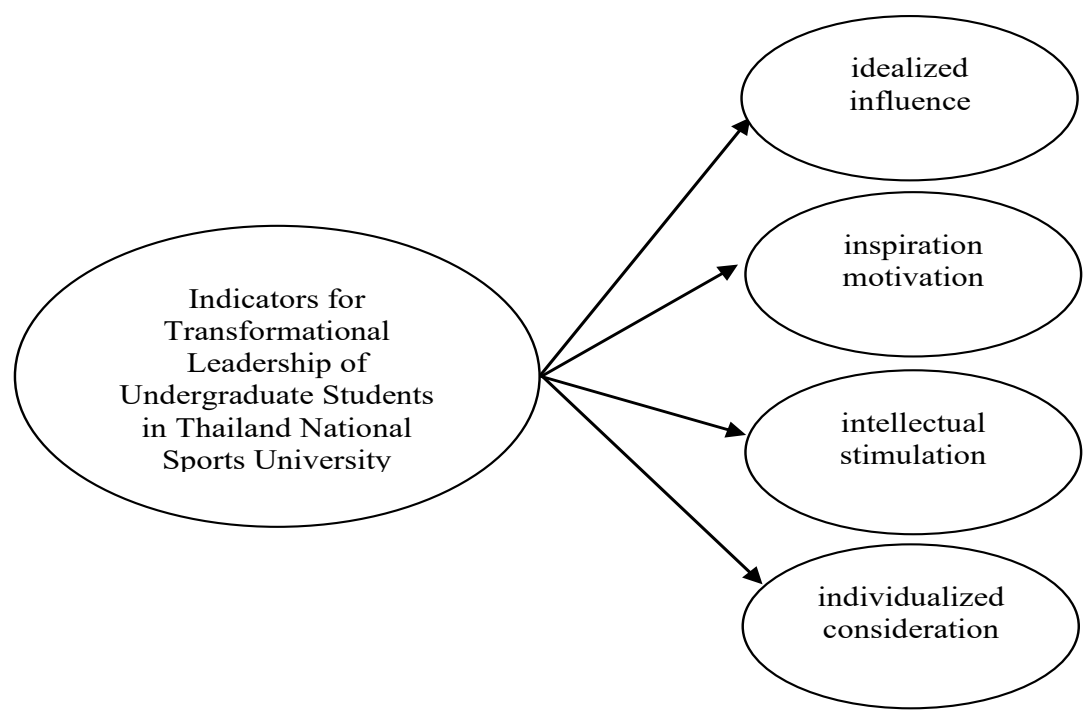

Figure 1. Conceptual Framework

This study is a mixed method research consisting of qualitative research to develop indicators and verify their suitability. The researchers took the concept of developing indicators of combined factors. This is done by combining various factors using the concept of transformational leadership mentioned above, studying creation concept of indicators by Johnstone (1981) and Wiratchai (2008), with context of undergraduate students at Thailand National Sports University as an input factor. The throughput used to obtain indicators consists of methods as follows. The data used to create the indicators was obtained by interviewing experts to discover suitable indicators for undergraduate students at Thailand National Sports University. Information from the interview was then synthesized using the conceptual framework of transformational leadership. The evaluation process is considered based on (1) accuracy standards, (2) propriety standards, and (3) utility standards. quantitative research, A hypothesis model was created to test the consistency of the structural model for indicators for transformational leadership of Undergraduate students at Thailand National Sports University with empirical data to obtain output.

\subsection{Hypothesis}

Indicators for transformational leadership of undergraduate students at Thailand National Sports University are consistent with empirical evidence.

\subsection{Ethical Considerations}

The researcher clearly explained the purpose and the procedures of the study to the participants and then obtained their informed consent. This study was approved by the Human Research Ethics Committee, Thailand National Sports University (certification number: TNSU 043/2563).

Every individual in the sample group was informed of terms and conditions and agreed to participate as the sample group of this research. The researchers personally explained the details of the research and provided a consent form for participators to sign. Consent was asked of volunteers or their rightful representatives. Aliases were used instead of real names. Moreover, names of those involved or caused impact on the sample group were not revealed. The research results were presented as conclusions, which were of no influence to those in the sample group.

\section{Phase 1}

\section{Research Process}

1) Study concepts, documents, textbooks, and researches related to transitional leadership, roles of students, and development of indicators. Use the data obtained to synthesize indicators that determine the framework of transitional leadership of undergraduate students at Thailand National Sports University. Create a five-question semi-structured in-depth interview. 
2) Have five experts verify the quality of the semi-structured in-depth interview to determine its validity by finding the index of item - objective congruency (IOC). The IOC value is between 0.60 and 0.80 . Then, the researchers selected six interviewees consisting of two vice deans of each of the three faculties (Arts, Sports and Health Science, and Education) via purposive selection. The researchers interviewed the interviewees face-to-face. Data was recorded, gathered, and sorted into categories specified in the interviews. The data was then analyzed to find its consistency via analytic induction. After that, the data was analyzed using the conceptual framework to create a guideline for questions to evaluate indicators for transformational leadership of undergraduate students at Thailand National Sports University. theory triangulation, theoretical perspectives are considered either in conducting the research or in interpreting the data.

3) Have five experts verify the evaluation form for transformational leadership of undergraduate students at Thailand National Sports University to determine its validity by finding the index of item - objective congruency (IOC). The IOC value is between 0.60 and 0.80 . Have five eminent persons with the following qualifications: (1) at least five years of experience in lecturing in universities that provide courses related to Physical Education and sports, health, or recreational activities, (2) possess a doctoral degree, (3) hold faculty or university management positions in universities that provide courses related to Physical Education and sports, health, or recreational activities for at least three years. The evaluation is considered based on (1) accuracy standards (2) propriety standards and (3) utility standards (Stuffle, Beam, et al. 2000). Compare the data against 3.50 criteria using one sample t-test. Then use the data that meet the criteria to create questionnaire on indicators for transformational leadership of undergraduate students at Thailand National Sports University.

\section{Results}

1) In-depth interview with six informants produced eight keywords and 22 subtopics on idealized influence, six keywords and 13 subtopics on inspiration motivation, six keywords and 14 subtopics on intellectual stimulation, and five keywords and 11 subtopics on individualized consideration as shown Tables 1 - 4 .

Table 1. Keywords and Subtopics on Idealized Influence

\begin{tabular}{|c|c|}
\hline Keywords & Subtopics \\
\hline $\begin{array}{l}\text { 1. Have vision and be able to } \\
\text { convey it }\end{array}$ & $\begin{array}{l}\text { 1) Display intelligence in short-term and long-term planning that is adaptable to changes. } \\
\text { 2) Be able to convey essential concepts. } \\
\text { 3) Be able to comment constructively rather than cause conflicts. }\end{array}$ \\
\hline $\begin{array}{l}\text { 2. Promote pride, loyalty, } \\
\text { and confidence }\end{array}$ & $\begin{array}{l}\text { 4) Create willingness, pride, joy, and unity when working together. } \\
\text { 5) Be down-to-earth and respect everyone's value. } \\
\text { 6) Have a well-respected image. }\end{array}$ \\
\hline $\begin{array}{l}\text { 3. Promote sense of unity to } \\
\text { achieve goals }\end{array}$ & $\begin{array}{l}\text { 7) Be determined to unite, help, and support team to complete tasks. } \\
\text { 8) Display strong belief and determination in achieving goals. }\end{array}$ \\
\hline 4. Self-confidence & $\begin{array}{l}\text { 9) Be confidently expressive with one's own thoughts, feelings, and actions. } \\
\text { 10) Perform tasks with self-belief. }\end{array}$ \\
\hline $\begin{array}{l}\text { 5. Deal with emotions and } \\
\text { stress during crisis }\end{array}$ & $\begin{array}{l}\text { 11) Express one's own feelings in an appropriate manner. } \\
\text { 12) Be able to deal with one's own sudden emotions that might cause problems with } \\
\text { appropriate and creative approaches. }\end{array}$ \\
\hline & $\begin{array}{l}\text { 13) Be able to offer solutions to internal conflicts with reason, facts, and positive } \\
\text { approaches. }\end{array}$ \\
\hline 6. Be moral and ethical & $\begin{array}{l}\text { 14) Manage with morality. Be transparent. } \\
\text { 15) Be moral and ethical in working and not abuse power for personal gains. } \\
\text { 16) Be a good example: honest, focused, disciplined, and behave morally to gain respect } \\
\text { from colleagues. }\end{array}$ \\
\hline & 17) Work using democracy as the foundation. \\
\hline 7. Focus on common interest & $\begin{array}{l}\text { 18) Overlook one's own personal gains. } \\
\text { 19) Seek new useful knowledge constantly. }\end{array}$ \\
\hline 8. Show high performance & $\begin{array}{l}\text { 20) Possess leadership. } \\
\text { 21) Possess academic skills. } \\
\text { 22) Possess professional skills. }\end{array}$ \\
\hline
\end{tabular}


Table 2. Keywords and Subtopics on Inspiration Motivation

\begin{tabular}{|c|c|}
\hline Keywords & Subtopics \\
\hline \multirow[t]{2}{*}{ 1. Have standards } & 1) Have high standards for working and believe in achieving goals. \\
\hline & 2) Create belief in one's own and team's abilities in completing objectives. \\
\hline \multirow[t]{2}{*}{ 2. Boost morale in working } & 3) Always be able to talk supportively. \\
\hline & 4) Always be able to give praise. \\
\hline \multirow[t]{3}{*}{ 3. Positive thinking } & 5) Use positive words and expressions. \\
\hline & 6) Look at problems optimistically and turn crises into opportunities. \\
\hline & 7) When mistakes happen, always be supportive and encouraging. \\
\hline \multirow[t]{2}{*}{ 4. Think ahead } & 8) Imagine future images and use them as concepts in studying and activities. \\
\hline & 9) Let followers experience positive images of the future. \\
\hline \multirow{2}{*}{$\begin{array}{l}\text { 5. Communication to } \\
\text { motivate }\end{array}$} & 10) Convince others to accept in participate in turning concepts into goals. \\
\hline & 11) Always have expectations and be able to express them. \\
\hline \multirow[t]{2}{*}{ 6. Encourage teamwork } & 12) Promote teamwork culture and values. \\
\hline & 13) Be able to form suitable groups to cooperate effectively. \\
\hline
\end{tabular}

Table 3. Keywords and Subtopics on Intellectual Stimulation

\begin{tabular}{ll}
\hline \multicolumn{1}{c}{ Keywords } & \multicolumn{1}{c}{ Subtopics } \\
\hline $\begin{array}{l}\text { 1. Encourage creative } \\
\text { thinking }\end{array}$ & 1) Be able to motivate working and support new ideas to complete tasks successfully. \\
2) Promote the use of innovation in operation. \\
3) Take risks and try creative new ideas. \\
4) Encourage everyone to share their own opinions and accept each other's. \\
5) Encourage everyone to participate in identifying problems and look at problems with \\
different perspectives.
\end{tabular}

Table 4. Keywords and Subtopics on Individualized Consideration

\begin{tabular}{ll}
\hline \multicolumn{1}{c}{ Keywords } & \multicolumn{1}{c}{ Subtopics } \\
\hline 1. Recognize value and & 1) Display approval and praises toward colleagues. \\
importance of others & 2) Display feelings or act in a way that makes colleagues feel understood and valued. \\
2. Understand personal & 3) Be able to analyze individual differences. \\
differences & 4) Do not criticize others' opinions, even if they are against one's own. \\
3. Promote counselling & 5) Be aware of the importance of advices among classmates and senior/junior students. \\
system & 6) Be able to provide advice to classmates and senior/junior students. \\
4. Create a co-working & 7) Converse casually. \\
atmosphere & 8) Create a warm atmosphere with open communication and trust. \\
5. Provide opportunities for & 9) Listen to recommendations carefully. \\
best performance & 10) Be open to different opinions.
\end{tabular}

2) Evaluation of verify indicators for transformational leadership of undergraduate students at Thailand National Sports University concluded that all indicators' accuracy, suitability, and benefit are above the 3.50 criteria with a statistical significance of .05 . 


\section{Phase 2}

\section{Research Process}

Have five authorities verify indicators for transformational leadership of undergraduate students at Thailand National Sports University to determine its validity by testing on 30 students who were not in the sample group. Reliability was calculated using Cronbach's alpha coefficient $(\alpha=0.88)$. Then, the researchers gathered data from students of Thailand National Sports University using the rule of thumb by Hair.; et al., (2018) and Schumacker \& Lomax (2016). This research has 25 variables with a ratio of 18:1. The sample group size was 450, selected using two-stage sampling. Stage 1: As Thailand National Sports University is spread across 17 campuses, each with three faculties including Education, Sports and Health Science, and Arts, students in every campus should be in similar context and of similar quality. Representatives from ten campuses were selected via simple random sampling. Stage 2: Forty-five students from each of the ten campuses were randomly selected, with 15 from each of the three faculties using stratified random sampling. Confirmatory factor analysis for the second order was conducted to verify structural validity of observable variables in each of the factors in indicators for transformational leadership of undergraduate students at Thailand National Sports University using maximum likelihood (ML). Important statistics used in verifying consistency of indicators and empirical data are relative $\chi 2$ (Chi - Square /df), Goodness of Fit Index (GFI), Adjusted Goodness of Fit Index (AGFI), Normal Fit Index (NFI), Comparative Fit Index (CFI), and Root Mean Square Error of Approximation (RMSEA) (Joreskog \& Sorbom, 1996; Diamantopoulos \& Siguaw, 2000).

\section{Results}

1) Verification of suitability in factor analyzation concluded that Kaiser-Mayer-Olkin measure of sampling adequacy index is 0.921 . Bartlett's test of sphericity's statistics is 10863.731 with statistical significance $(p=.00)$. This is highly suitable for analyzing factors as follows.

Table 5. Analysis of Confirmatory Factor (first order) for Indicators for Transformational Leadership of Undergraduate Students at Thailand National Sports University

\begin{tabular}{|c|c|c|c|c|c|c|}
\hline \multirow[t]{2}{*}{ Factor } & \multirow[t]{2}{*}{ Indicators } & \multicolumn{4}{|c|}{ Factor Loading } & \multirow{2}{*}{$\mathrm{R}^{2}$} \\
\hline & & $\mathrm{b}$ & $\mathrm{B}$ & SE & $\mathrm{t}$ & \\
\hline \multirow[t]{8}{*}{ II } & 1. Have vision and be able to convey it & 0.55 & 0.55 & 0.04 & $14.01 * *$ & 0.39 \\
\hline & 2. Promote pride, loyalty, and confidence & 0.63 & 0.63 & 0.04 & $14.62 * *$ & 0.42 \\
\hline & 3. Promote sense of unity to achieve goals & 0.44 & 0.44 & 0.03 & $13.21 * *$ & 0.35 \\
\hline & 4. Self-confidence & 0.55 & 0.55 & 0.04 & $13.84 * *$ & 0.38 \\
\hline & 5. Deal with emotions and stress during crisis & 0.48 & 0.48 & 0.04 & $11.08^{* *}$ & 0.26 \\
\hline & 6. Be moral and ethical & 0.60 & 0.60 & 0.04 & $12.96 * *$ & 0.34 \\
\hline & 7. Focus on common interest & 0.55 & 0.55 & 0.04 & $13.21 * *$ & 0.35 \\
\hline & 8. Show high performance & 0.54 & 0.54 & 0.04 & $11.52 * *$ & 0.28 \\
\hline \multirow[t]{6}{*}{$\mathrm{IM}$} & 1. Have standards in working & 0.38 & 0.38 & 0.04 & $8.74 * *$ & 0.18 \\
\hline & 2. Boost morale in working & 0.54 & 0.54 & 0.04 & $13.36^{* *}$ & 0.38 \\
\hline & 3. Positive thinking & 0.51 & 0.51 & 0.03 & $12.98 * *$ & 0.37 \\
\hline & 4. Think ahead & 0.35 & 0.35 & 0.03 & $9.98 * *$ & 0.23 \\
\hline & 5. Communication to motivate & 0.45 & 0.45 & 0.04 & $10.61 * *$ & 0.26 \\
\hline & 6. Encourage teamwork & 0.36 & 0.36 & 0.03 & $11.37 * *$ & 0.29 \\
\hline \multirow[t]{6}{*}{ IS } & 1. Encourage creative thinking & 0.48 & 0.48 & 0.04 & $12.06^{* *}$ & 0.30 \\
\hline & 2. Brainstorm & 0.54 & 0.54 & 0.03 & $14.42 * *$ & 0.41 \\
\hline & 3. Active working & 0.60 & 0.60 & 0.04 & $14.87 * *$ & 0.43 \\
\hline & 4. Solve problems systematically & 0.61 & 0.61 & 0.04 & $13.02 * *$ & 0.35 \\
\hline & 5. Create changes & 0.47 & 0.47 & 0.04 & $10.89^{* *}$ & 0.26 \\
\hline & 6. Create confidence in overcoming obstacles & 0.45 & 0.45 & 0.05 & $9.16^{* *}$ & 0.19 \\
\hline \multirow[t]{5}{*}{ IC } & 1. Recognize value and importance of others & 0.64 & 0.64 & 0.04 & $14.66^{* *}$ & 0.43 \\
\hline & 2. Understand personal differences & 0.57 & 0.57 & 0.04 & $13.26^{* *}$ & 0.37 \\
\hline & 3. Promote counselling system & 0.53 & 0.53 & 0.04 & $13.38^{* *}$ & 0.37 \\
\hline & 4. Create a co-working atmosphere & 0.51 & 0.51 & 0.04 & $11.76^{* *}$ & 0.30 \\
\hline & 5. Provide opportunities for best performance & 0.57 & 0.57 & 0.04 & $11.84 * *$ & 0.30 \\
\hline
\end{tabular}

\footnotetext{
$* * \mathrm{p}<.01$
} 
2) Factor weight of indicators for transformational leadership of undergraduate students at Thailand National Sports University are all found to be positive with a statistical significance of .01 . The indicator with the most weight in idealized influence factor is promoting pride, loyalty, and confidence. The indicator with the most weight in inspiration motivation factor is boosting morale in working. The indicator with the most weight in intellectual stimulation factor is solving problems systematically. The indicator with the most weight in individualized consideration factor is recognizing value and importance of others as shown Table 5.

3) Analysis of confirmatory factor (first order) for indicators for transformational leadership of undergraduate students at Thailand National Sports University found that relative $\chi 2$ at 2.04 (chi-square $(\chi 2)$ was at 552.93; (probability-value [p-value] at 0.000); degrees of freedom (df) at 271); goodness of fit index (GFI) at 0.91; adjusted goodness of fit index (AGFI) at 0.90; Normal Fit Index (NFI) at 0.99; Comparative Fit Index (CFI) at 0.99 and the root mean square error of approximation (RMSEA) at 0.04 . Therefore, it is accepted that the research model is consistent with empirical data as shown in Table 6.

Table 6. Goodness of Fit Index In Analyzing Confirmatory Factors (second order) for Model Indicators for Transformational Leadership of Undergraduate Students at Thailand National Sports University

\begin{tabular}{ccccc}
\hline Fit Indicates & Perfect Fit & Acceptable fit & Study Finding & Result \\
\hline relative $\chi^{2}$ & $<2.00$ & $2.00-5.00$ & 2.04 & Acceptable fit \\
GFI & $\geq .95$ & $0.90-0.94$ & 0.91 & Acceptable fit \\
AGFI & $\geq .95$ & $0.90-0.94$ & 0.90 & Acceptable fit \\
NFI & $\geq .95$ & $0.90-0.94$ & 0.97 & Perfect fit \\
CFI & $\geq .95$ & $0.90-0.94$ & 0.99 & Perfect fit \\
RMSEA & $<0.05$ & $0.05-0.08$ & 0.04 & Perfect fit \\
\hline
\end{tabular}

4) Analysis of factor weight found that the weights were all positive with a statistical significance of .01. Intellectual stimulation (IS) has the most standard factor weight of 0.99 followed by idealized influence (II) at 0.97 , followed by individualized consideration (IC) at 0.96, and inspiration motivation (IM) at 0.90 as shown in Table 7 and Figure 2.

Table 7. Analysis of Confirmatory Factors (Second Order) for Model Indicators for Transformational Leadership of Undergraduate Students at Thailand National Sports University

\begin{tabular}{|c|c|c|c|c|c|}
\hline \multirow[t]{2}{*}{ Factor } & \multicolumn{4}{|c|}{ Factor Loading } & \multirow{2}{*}{$\mathrm{R}^{2}$} \\
\hline & $\mathrm{b}$ & $\mathrm{B}$ & $\mathrm{SE}$ & $\mathrm{t}$ & \\
\hline II & 0.97 & 0.97 & 0.07 & $13.66^{* *}$ & 0.94 \\
\hline IM & 0.90 & 0.90 & 0.11 & $8.50 * *$ & 0.81 \\
\hline IS & 0.99 & 0.99 & 0.08 & $12.01 * *$ & 0.98 \\
\hline IC & 0.96 & 0.96 & 0.06 & $14.30 * *$ & 0.92 \\
\hline
\end{tabular}

$* * \mathrm{p}<.01$

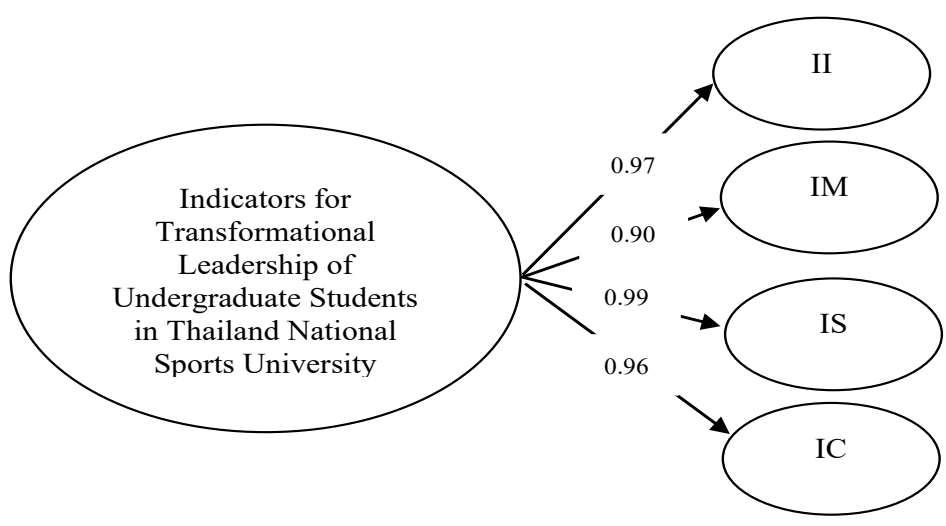

Figure 2. Factors (Second Order) for Model Indicators for Transformational Leadership of Undergraduate Students in Thailand National Sports University 
5) Analysis of construct reliability found that idealized influence (II) has a construct reliability of high level ( $\rho$ c $=0.81$ ). Inspiration motivation (IM) has a construct reliability of high level $(\rho c=0.70)$. Intellectual stimulation (IS) has a construct reliability of high level $\rho \mathrm{c}=0.74)$. Individualized consideration $(\mathrm{IC})$ has a construct reliability of high level $(\rho \mathrm{c}=0.73)$ as shown in Table 8 .

Table 8. Construct Reliability ( $\rho c$ ) for Latent Variables in Analysis of Confirmatory Factors (Second Order)

\begin{tabular}{cc}
\hline Latent Variable & Construct reliability $(\rho \mathrm{c})$ \\
\hline Il & 0.81 \\
IM & 0.70 \\
IS & 0.74 \\
IC & 0.73 \\
\hline
\end{tabular}

\section{Discussion and Conclusions}

1) Intellectual stimulation is the most important aspect of character, since students who are assigned tasks or activities are required to stimulate their colleagues' creativity. It is necessary that they take risks and initiate creativity. They use innovations to assist in their operation. This is consistent with Borodina, Sibgatullina, \& Gizatullina (2019) who stated that the expression of creativity is the foundation of university students who display leadership. Miller \& Dumford (2016) also found that the process of creative thinking and awareness among university students could occur via activities. Students have to brainstorm and motivate all group members to share their thoughts reasonably and accept others' opinions. They should promote participation in identifying problems and assessing problems from different perspectives. They should also be able to predict future circumstances using existing information. Systematic problem solving, constructive criticism, and proper use of information should be utilized in analyzing problems and obstacles. Students should analyze situations and opportunities in various aspects. Once changes happen, they should be able to choose a suitable approach to deal with those changes. Students should also communicate and understand changes. This supports Moman (2012), who studied transformational leadership required for leaders in higher education. It is found that transformational leadership depends on individual quality. Leaders are decisive and can encourage all group members to reach full intellectual potential. Sawasn \& Ibrahim (2018) stated that transformational leadership has positive impacts on higher education management. It stimulates intellectual and greatly affects knowledge sharing and gathering.

2) Idealized Influence is second in terms of importance since students who conduct themselves as good examples are respectable and trusted leaders. They instill pride in their followers when they work together. This ensures all group members feel happy, proud, willing, and united when working together. Good leaders should be down-to-earth, respect everyone's values, and have images worthy of approval. This is consistent with Bass (1999), who stated that idealized influencing is a behavior that leaders display in systematic management or operation. Followers approve of leaders who lead by example or act as a role model. Followers will attempt to behave the way their leader does and imitate them. For these reasons, transformational leaders must be determined to unite and assist their followers in order to achieve their tasks. Leaders should show confidence and resolution to achieve their goals. Students also need to show their emotions appropriately and deal with their feelings properly and creatively, as well as offer solutions to any disputes within the group with positive approaches. This supports Anderson (2019) who found that leaders need to display emotional intelligence, manage their own emotions, and keep themselves composed. They also need to be moral and ethical in their work, and not abuse their powers for personal gain. They should perform their duties on the basis of democracy. This is consistent with Maftei \& Holman (2020) who found that moral and ethical awareness among students stem from their behaviors toward others. In other words, they need to emphasize common interests rather than personal gains. Students also need to display high performance in leadership, academic abilities, and professional abilities.

3) Individual consideration is the third most important factor. Students should consider each individual's abilities and recognize others' value and importance. This can be achieved via displays of acceptance, compliments, understanding, and care toward their colleagues. They should understand individual differences and be able to analyze them. It is not appropriate to criticize others' ideas when they think differently. Leaders should be aware of the importance of counselling between fellow students and between senior and junior students. Carmeli, Sheaffer, Binyamin, Reiter-Palmon, \& Shimoni (2014) stated that creating a working atmosphere where individual differences are understood can lead to direct and indirect mental security. This promotes creative problem-solving, which is an 
approach for transformational leaders. It helps develop and instill abilities to solve problems creatively, open-mindedness. It encourages listening to different opinions and provides opportunities for ideas and knowledge exchange. This is in accord with Eratli, Özge, \& Pervin (2018) who found that Physical Education teachers are highly aware of transformational leaderships in terms of individual consideration.

4) Inspiration motivation is the least important factor since students need to use positive languages and speech. They should look at problems with optimism and turn crises into opportunities. When mistakes occur, they still support and encourage others. They are capable of thinking ahead and imaginng the future. Those ideas and imaginations can serve as guidelines for learning and activities. Leaders are capable of motivational and convincing communications. They should draw others to participate in realizing their thoughts and achieving their goals while clearly express their expectations. Hayles (2019) found that inspiration motivation causes positive changes in behaviors among students. They learn from experiences and form new knowledge. In addition, students exchange and communicate ideas on future careers. They also need to encourage teamwork and promote culture. Teamwork values can form groups of suitable individuals to cooperatively perform tasks with effectiveness. Lamm, Sapp, \& Lamm (2016) found that transformational leadership serve as models for leaders who focus on the positives, which emphasize motivation and efficiency. This leads to an improvement of effectiveness in organizations. Moreover, motivation can be predicted. Thus, learning is achievable (Noland \& Richards, 2014).

Indicators for transformational leadership of undergraduate students at Thailand National Sports University developed were suitable and consistent with empirical data. They had a high level of construct reliability. Therefore, they were appropriate indicators for transformational leadership considering the conditions and contexts of undergraduate students at Thailand National Sports University who will graduate and pursue careers using leadership in sports and fitness organizations such as Physical Education teachers, sports instructors, sports scientists, sports entrepreneurs, sports journalists, recreational activity leaders, and sports tour guides. Transformational leadership in students will instill behaviors of leaders who cause changes and motivate others by their own leadership. They are able to create bonds with the university or organization's objectives, inspire others, and bring out potential by taking individual differences into consideration. These changes affect values, beliefs, attitudes, morals, and behaviors in working which result in constant improvement of the organizations in which students will work. This is in accord with Aguas, Zapata, and Arellano (2017) who stated that higher education curricula are strategies to develop individual leadership. Higher education institutes should develop plans to create transformational leadership. Moreover, class management must guarantee that students will develop leadership skills to use in their future workplaces. Transformation leadership is able to improve leadership in the $21^{\text {st }}$ century in the following areas. 1) Learning and innovation skills consist of creativity, innovation, critical thinking, problem solving, communication, and cooperation. 2) Information and information technology skills. 3) Life and career skills consist of flexibility, adaptability, initiation, individualism, societal skills, cross-cultural skills, craftmanship, leadership, and responsibility.

\section{Recommendations}

Lecturers and Chairpersons of Thailand National Sports University can use the result of this research as guidelines in management of undergraduate curriculum. This research can lead to development of transformational leadership among students. Thus, education management achieves effectiveness. Standards of education in specialized higher education institutes can be improved. This research has developed indicators from research process and verified empirical data. Therefore, it can indicate transformational leadership suitable to conditions and contexts for undergraduate students at Thailand National Sports University. Lecturers in courses related to leadership or those in charge of Physical Education management can use these indicators for transformational leadership of undergraduate students at Thailand National Sports University as examples in their classes.

\section{Suggestion for Further Research}

Further research should take transformational leadership indicators for undergraduate students at Thailand National Sports University to evaluate students. This research could also serve as a prototype for future studies. The focus should be on development of transformational leadership in students in fields related to Physical Education and Sports. Theories and opinions from experts in various fields should be studied and analyzed in terms of explorative elements for consistency with the context of undergraduate curriculum in Physical Education. For example, use innovation as part of curriculum development strategy in which every personnel is required to contribute to management in order to create new innovations and improvement in the use of language. Moreover, transformational 
leadership in students should be developed at a higher level such as post-graduate level. Also, multi-group elements can be analyzed in context of students in fields related to Physical Educations and Sports between government and government-managed universities and Thailand National Sports University and Rajabhat Universities.

\section{Acknowledgments}

The researchers would like to express their gratitude to Thailand National Sports University, Chon Buri Campus, for funding the research on The Development of Indicators for Transformational Leadership of Undergraduate students at Thailand National Sports University.

\section{References}

Abubakar, A., \& Ahmed, S. (2017). The Effect of a Transformational Leadership Style on the Performance of Universities in Nigeria. PJER, 2(1), 59-76.

Aguas, P., Zapata, L.V., \& Arellano, D. L. (2017). Transformational Leadership Plans. World Journal of Education, 7(4), 1-11. https://doi.org/10.5430/wje.v7n4p1

Alshehri, A., \& Cumming, T. M. (2020). Mobile Technologies and Knowledge Management in Higher Education Institutions: Students' and Educators' Perspectives. World Journal of Education, 10(1), 12-22. https://doi.org/10.5430/wje.v10n1p12

Anderson, C. J. (2019). A Leader's Emotional Self-Control and Management of Others Impacts a School's Climate. Journal of Invitational Theory and Practice, 25, 39-57. https://files.eric.ed.gov/fulltext/EJ1251826.pdf

Bass, B. M. (1999). Two Decades of Research and Development in Transformational Leadership. European Journal of Work and Organizational Psychology, 8(1), 9-32.

Beer, M. (2010). Managing Change and Transition. Boston: Harvard Business School.

Bennis, W. G. (2009). On becoming a leader (Rev. and updated). New York: Basic Books.

Borodina, T., Sibgatullina, A., \& Gizatullina, A. (2019). Developing Creative Thinking in Future Teachers as a Topical Issue of Higher Education. Journal of Social Studies Education Research, 10(4), 226-245. https://files.eric.ed.gov/fulltext/EJ1241711.pdf

Carmeli, A., Sheaffer, Z., Binyamin, G., Reiter-Palmon, R., \& Shimoni, T. (2014). Transformational Leadership and Creative Problem-Solving: The Mediating Role of Psychological Safety and Reflexivity. Journal of Creative Behavior, 48(2), 115-135. http://dx.doi.org/10.1002/jocb.43

Crowne, K. A. (2019). Investigating Antecedents of Transformational Leadership in Students. Journal of International Education in Business, 12(1), 80-94. https://doi.org/10.1108/JIEB-07-2018-0029

Dempster, N., \& Lizzio, A. (2007). Student leadership: necessary research. Australian Journal of Education, 51(3), 276-285. https://doi.org/10.1177/000494410705100305

Diamantopoulos, A., \& Siguaw, J. A. (2000). Introducing LISREL. London: Sage Publications. https://dx.doi.org/10.4135/9781849209359

Eratli, S. Y., Özge, A., \& Pervin, B. F. (2018). Transformational-Transactional Leadership an Organizational Cynicism Perception: Physical Education and Sport Teachers Sample. Universal Journal of Educational Research, 6(9), 2008-2018. https://dx.doi.org/10.13189/ujer.2018.060920

Ewell, J. (2018). Revitalizing a Student Organization by Applying Transformational Leadership. Journal of Leadership Education, 17(3), 208-218.

Fardillah, L., Prasetyo, B., \& Yunike Putri, R. (2018). Transformational Leadership in Higher Education Institutions and Employee Satisfaction Interventions. In Proceedings of the 2nd International Conference Postgraduate School (ICPS 2018), 721-724. https://dx.doi.org/10.5220/0007550307210724

Gott, T., Bauer, T., \& Long, K. (2019). Student Leadership Today, Professional Employment Tomorrow. New Directions for Student Leadership, 162, 91-109. https://doi.org/10.1002/yd.20336

Hair, Jr., J. F., Black, W. C., Babin, B. J., Anderson, R. E., \& Black, R. L., W.C. (2018). Multivariate Data Analysis (8th ed.). Upper Saddle River, NJ: Pearson Prentice Hall.

Hayles, C. S. (2019). Inspire Sustainability Internships: Promoting Campus Greening Initiatives through Student 
Participation. International Journal of Sustainability in Higher Education, 20(3), 452-469. http://dx.doi.org/10.1108/IJSHE-03-2019-0111

Johnstone, J. N. (1981). Indicators of Education Systems. London: Unesco.

Joreskog, K., \& Sorbom, D. (1996). LISREL 8 User's Reference Guide. Chicago: Scientific Software International.

Jovanovica, D., \& Ciric, M. (2016). Benefits of Transformational Leadership in the Context of Education. European Proceedings of Social and Behavioural Sciences (EpSBS), 496-503. https://dx.doi.org/10.15405/EPSBS.2016.09.64

Lamm, K. W., Sapp, L. R., \& Lamm, A. J. (2016). Leadership Programming: Exploring a Path to Faculty Engagement in Transformational Leadership. Journal of Agricultural Education, 57(1), 106-120. https://dx.doi.org/10.5032/jae.2016.01106

Maftei, A., \& Holman, A. (2020). Representation of Morality in Children: A Qualitative Approach. Journal of Moral Education, 49(2), 194-208. http://dx.doi.org/10.1080/03057240.2019.1619542

Meepadung S Noichun \& Yafu, N. (2015). Developing Strategies of Student Affairs to Promote Student Leadership of the Institute of Physical Education. Humanities and Social Sciences. Journal of Pibulsongkram Rajabhat University, 9(2), 207-224.

Melanie, K, S., \& Vilmos, V. (2019). Towards creative transformational leadership in higher education: Challenges and opportunities. Journal of Institute for Educational Research, 51(1), 238-284 https://doi.org/10.2298/ZIPI1901238S

Miller, A. L., \& Dumford, A. D. (2016). Creative Cognitive Processes in Higher Education. Journal of Creative Behavior, 50(4), 282-293. http://dx.doi.org/10.1002/jocb.77

Minhyun, K., Glenn, H., Lauren, H., \& Hosung, S. (2017). The Effect of Transformational Leadership on Middle School Students' Intrinsic Motivation and Expectancy-Value in Physical Education. European Journal of Educational Sciences, 4(2), 22-31. http://dx.doi.org/10.19044/ejes.v4no2a2

Moman, B. L. (2012). Transformational Leadership Characteristics Necessary for Today's Leaders in Higher Education. Journal of International Education Research, 8(4), 343-348.

Neumeister, J. R. (2017). The Model of Transformational Change for Moral Action: A Conceptual Framework to Elevate Student Conduct Practice in Higher Education. Journal of College and Character, 18(2), 97-111. http://dx.doi.org/10.1080/2194587X.2017.1300097

Noland, A., \& Richards, K. (2014). The Relationship among Transformational Teaching and Student Motivation and Learning. Journal of Effective Teaching, 14(3), 5-20. https://files.eric.ed.gov/fulltext/EJ1060434.pdf

Nurtjahjani, F., Noermijati, N., Hadiwidjojo, D., \& Irawanto, D. W. (2019). Transformational Leadership in Higher Education:(A Study in Indonesian Universities). 3rd Asia Pacific International Conference of Management and Business Science (AICMBS 2019). 195-101.

Office of the National Economic and Social Development Board. (2017). The 12th National Economic and Social Development Plan (2017-2021). Bangkok: Office of the National Economic and Social Development Board.

Office of the Permanent Secretary of Ministry of Tourism and Sports, Thailand .(2016). The 6th National Sport Development Plan (2017-2021). Bangkok: Office of the War Veterans Organization Printing House.

Rosch, D. M., \& Collins, J. D. (2017). The Significance of Student Organizations to Leadership Development. New Directions for Student Leadership, 2017(155), 9-19. https://doi.org/10.1002/yd.20246

Sangkhawan, J. (2015). Strategic Leadership. Bangkok: SE-EDUK.

Sawasn, H., \& Ibrahim, E. (2018). Evaluating the Effect of Transformational Leadership on Knowledge Sharing Using Structural Equation Modelling: The Case of Iraqi Higher Education. International Journal of Leadership in Education, 21(4), 506-517. http://dx.doi.org/10.1080/13603124.2016.1142119

Schumacker, R., \& Lomax, R. (2016). A Beginner's Guide to Structural Equation Modeling (4th ed.). New York: Routledge.

Shabazz, J. (2020). Transformational Leadership: Motivating Students to Learn. Retrieved from http://hdl.handle.net/20.500.12419/475

Skalicky, J., Warr, P. K., Jacques, M., Fuglsang, S., Dawson, P., \& Stewart, S. (2020). A Framework for Developing 
and Supporting Student Leadership in Higher Education. Studies in Higher Education, 45(1), 100-116. http://dx.doi.org/10.1080/03075079.2018.1522624

Stufflebeam, D. L. (2000). Foundational models for 21st century program evaluation. In Stufflebeam, D.L., Madaus, G. F., \& Kellaghan, T. (Eds.), Evaluation models: Viewpoints on educational and human services evaluation (2nd ed.) (pp. 33-83). Newell, MA: Kluwer.

Taat, M. S., \& Francis, A. (2020). Factors Influencing the Students' Acceptance of E-Learning at Teacher Education Institute: An Exploratory Study in Malaysia. International Journal of Higher Education, 9(1), 133-141. https://doi.org/10.5430/ijhe.v9n1p133

Thailand National Sports. (2018). National Sports University Strategy 2018 - 2022. Bangkok: National University of Sports Ministry of Tourism and Sports.

The Commission drives the country's reform. (2017). Report on the reforming of the higher education system. Bangkok: The Secretariat of the Council Representatives.

Ustun, D. U. (2018). Transformational Leadership Behaviors of High School Students'According to Leisure Preferences and Participation Type. World Journal of Education, 8(4), 18-23. https://doi.org/10.5430/wje.v8n4p18

Wiratchai, N. (2008). Research and indicators of mechanics. Bangkok: Preparation and Development Center Training to develop teaching skills and develop knowledge (minister).

Yukl, G. (2020). Leadership in Organizations (9th ed.). Boston: Pearson Education.

\section{Copyrights}

Copyright for this article is retained by the author(s), with first publication rights granted to the journal.

This is an open-access article distributed under the terms and conditions of the Creative Commons Attribution license (http://creativecommons.org/licenses/by/4.0/). 